Much of the personal work referred to was supported by a grant from the Medical Research Council.

Figs. 2, 3 and 4 in this paper are taken from Nature, Lond. 222, 629 and are reproduced with the permission of the Editor of Nature.

\title{
REFERENCES
}

Adolph, E. F. (1947). Am. F. Physiol. 151, 1 10.

Brobeck, J. R. (1948). Yale J. Biol. Med, 20, 545.

Dewar, A. D. (1957). F. Endocr. 15, 2 16.

Dumin, J. G. V. A. (1961). F. Physiol., Lond. 156, 294.

Edholm, O. G., Fletcher, J. G., Widdowson, E. M. \& McCance, R. A. (I955). Br. Y. Nutr. 9, 286.

Hervey, E. \& Hervey, G. R. (1966). I. Physiol., Lond. r87, 44P.

Hervey, E. \& Hervey, G. R. (1967). F. Endocr. 37, 36r.

Hervey, E. \& Hervey, G. R. (1969). F. Physiol., Lond. 200, 118 P.

Hervey, E., Hervey, G. R. \& Berry, P. M. (1967). F. Endocr. 38, iv.

Hervey, E., Hervey, G. R., Hutchinson, I. \& Jeffery, J. d'A. (r969). F. Endocr. 45, ii.

Hervey, G. R. (1959). F. Physiol., Lond. 145, 336 .

Hervey, G. R. (1962). Excerpta Med. Intern. Cong. Ser, 47, 688.

Hervey, G. R. (1964). Proc. Nutr. Soc. 23, xxii.

Hervey, G. R. (I969a). Nature, Lond. 222, 629.

Hervey, G. R. (1969b). Proc. Nutr. Soc. 28, 54A.

Hervey, G. R. \& Hervey, E. (I964). F. Endocr, 3o, vii.

Hervey, G. R. \& Hervey, E. (1965). F. Endocr. 33, ix.

Janowitz, H. D. \& Hollander, F. (1955). Ann. N.Y. Acad. Sci. 63, 56.

Kennedy, G. C. (1953). Proc. R. Soc. B. 140, 578.

Mayer, J. (1952). Bull. New Engl. med. Cent. 14, 43.

Mayer, J. (1955). Ann. N.Y. Acad Sci. 63, 15.

Miller, D. S., Mumford, P. \& Stock, M. J. (1967). Am. F. clin. Nutr. 20, 1223.

Richter, C. P. (1956). Proceedings of the Second Fosiah Macy Conference p. I I. Baltimore: Josiah Macy Foundation.

Widdowson, E. M., Edholm, O. G. \& McCance, R. A. (r954). Br. F. Nutr. 8, I47.

\section{Metabolic and physical control of food intake in ruminants}

\author{
By J. A. Bines, National Institute for Research in Dairying, Shinfield, \\ Reading $R G 29 A T$
}

\section{Introduction}

Various aspects of the regulation of food intake in ruminants have recently been reviewed by Campling (1970), Baumgardt (1970), Baile \& Mayer (1970) and Arnold (1970) in greater detail than is possible here. This paper will attempt to integrate this information for the housed ruminant, with emphasis on those points of particular interest to the author.

The total amount of food eaten by an animal in a given period of time depends on (I) the number of meals eaten in that time, (2) the length of each meal, (3) the rate of eating during each meal. Factors affecting food intake may operate by changing one or more of these; a change in one may be compensated for by an opposite change in one or both the others. Therefore, it is often important to consider the net effect on the total amount of food eaten in a period of time, which may be different from the effect expected if one of the above were studied in isolation from the others. 


\section{Physical control}

The bulky nature of the foods eaten by most wild ruminants and, until quite recent times, by domestic ruminants often results in the rumen being filled to capacity before enough food has been consumed to meet the nutrient requirements for maximum production. With this type of food, intake is controlled by the capacity of the alimentary tract and, particularly of the rumen, the rate at which the food is chemically broken down by the processes of digestion and the rate at which the undigested residues of the food are broken down physically before they can be moved on from the rumen.

Rumen capacity. The principal determinant of rumen capacity is the size of the animal; thus, when food of a relatively low digestibility is given to a number of animals, intake is broadly related to [live weight $]^{1.0}$ (Conrad, Pratt \& Hibbs, 1964). In part, at least, this is determined by the size of the abdominal cavity, which appears to be limited in the extent to which it can stretch. Thus, in early pregnancy, roughage intake can be maintained or even increased and the abdomen can be seen to become more distended. Eventually, however, further distension is apparently not possible, foetal enlargement within the abdominal cavity occurs at the expense of rumen capacity and food intake is often reduced (Forbes, 1969). Nevertheless, the animal is apparently able to increase the rate of passage of the food as pregnancy advances, thus helping to offset the decline expected due to compression of the rumen (Graham \& Williams, I962; Forbes, 1970). On the other hand, Lamberth (1969) could find no differences between pregnant and non-pregnant twin heifers in rumen volume and rate of passage even though the intake of the pregnant twins was always reduced.

In fat animals, extensive deposition of fat within the abdominal cavity (e.g. mesenteric and omental fat) apparently reduces the effective capacity of the cavity and this is associated with a reduced roughage intake by these animals (Tayler, 1959; Forbes, 1969; Bines, Suzuki \& Balch, 1969). This reduction in intake is not necessarily an effect of a physical regulatory mechanism, since concentrate intake is also reduced in fat animals without the rumen being filled to capacity (Bines et al. 1969). However, since fat cows do not eat enough hay even to maintain their weight, whereas thin cows eat enough of the same hay to gain weight (Bines, unpublished), the existence of a physical regulator appears likely.

In the lactating cow it is possible that the increased demand for nutrients can be met in part by what has been termed a hypertrophy of the alimentary canal, thus permitting an increased food intake (Leaver, Campling \& Holmes, 1969).

Rate of chemical breakdown of food in the rumen. In the ruminant, this is the rate at which enzymatic digestion of the food by the rumen micro-organisms occurs; it is, therefore, closely related to the chemical composition of the food. Numerous workers have noted the resultant relationship between the digestibility and intake of roughages (e.g. Blaxter \& Wilson, 1962; Conrad et al. 1964). When a low-quality roughage is given, the rate of breakdown is usually very slow. Addition of nitrogen to the rumen, however, increases microbial activity, and hence rate of breakdown 
and voluntary intake of this type of food (e.g. Campling, Freer \& Balch, 1962). Conversely, the addition of grain to a ration of hay has been shown to reduce intake of the hay, apparently due to a reduction in the cellulolytic activity of the rumen microflora (Campling, r 966 ).

Rate of passage of undigested food residues. This combines with the previous factor to influence the rate of disappearance of digesta from the rumen. Passage of undigested residues from the rumen depends on physical breakdown of the food into particles small enough to pass out of the rumen (Pearce, 1967). Thus, as the proportion of structural carbohydrate in a food increases, the amount of time required for physical breakdown increases, and rate of passage and intake will decrease.

- Rate of passage may be increased by grinding the food before it is given to an animal; this will often increase the intake of that food (Minson, 1963) especially where it is a poorer-quality roughage (Campling, Freer \& Balch, 1963; Campling $\&$ Freer, 1966).

Physical regulation of food intake presumably involves stretch receptors in the wall of the rumen or abdomen, but the exact nature and location of these is not yet known (Comline, Silver \& Steven, I969).

\section{Metabolic control}

Regulation of energy balance. When a ruminant is given a concentrated diet, the amount of material in the rumen at the end of a meal is less than when the diet consists mainly of roughage (Bines \& Davey, 1970; Freer \& Campling, 1963); thus, some factor has assumed greater importance than rumen fill in the regulation of food intake. At a single meal, there is considerable variation between different diets in the amount eaten, considerably less of an all-concentrate diet being eaten than of one containing a small proportion of roughage (Bines \& Davey, 1970). However, when the total amount of food consumed in a day or longer period is considered, there is strong evidence that, with a concentrate diet, an animal's total intake of digestible energy is constant regardless of the exact composition of the ration fed (Dinius \& Baumgardt, 1970). Thus, as the digestible energy concentration of the food increases above a certain value, dry-matter intake will decrease in order that digestible energy intake may remain constant (Fig. I). The level of digestible energy concentration at which this occurs is, therefore, the point at which the regulation of food intake changes from physical to metabolic in nature and it will vary between animals according to the different physiological states, and hence energy requirements, of those animals (Fig. I).

Relationship of intake to energy demand. An animal uses energy-yielding metabolites absorbed from the gut for various synthetic, productive processes as well as for maintenance and heat production. In a given physiological state, the animal performs those processes of which it is capable to the maximum limit set by its genetic make-up, provided intake of energy and other nutrients is not limiting. Under these conditions, total energy expenditure equals total energy intake, provided that the ration is sufficiently concentrated. Variations in production due to 


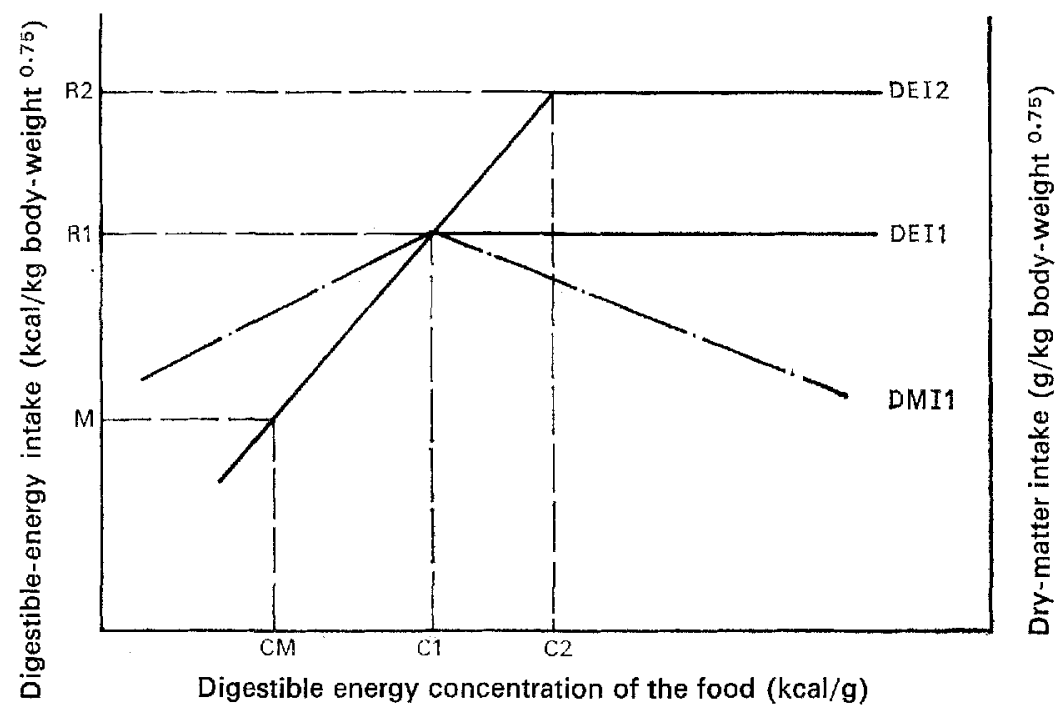

Fig. 1. The relationships between the voluntary intakes of digestible energy (DEI) and dry matter (DMI), and the digestible energy concentration of the food for ruminant animals requiring a lower $\left(R_{I}\right)$ and a higher $\left(R_{2}\right)$ level of digestible energy to maximize their production. $M$ is the digestible energy requirement for maintenance. $\mathrm{CM}, \mathrm{C}_{\mathrm{I}}$ and $\mathrm{C}_{2}$ are the minimum digestible energy concentrations in the diet that will enable these various requirements to be met and hence they are the points at which the mechanism of regulation of food intake changes in nature from physical to metabolic.

changes in the physiological state of the animal are reflected in changes in intake. Thus, intake is dependent on the metabolic size of the animal, its production and ration digestibility (Conrad et al. 1964).

Selection of suitable animals permits an examination of the individual effects of productive processes on food intake. In grazing animals, Arnold (I966) found that 6-month-old growing sheep ate $5 \mathrm{~g} / \mathrm{kg}$ more digestible organic matter than 3 -yearold sheep. Pregnancy results in an increased food intake during its earlier stages although this effect is usually masked by a reduction in intake in later pregnancy when physical and hormonal effects become dominant (Forbes, 1970). Lactation has a marked effect on food intake, resulting in increases of up to $80 \%$ over 'dry' animals (Forbes, I970). However, in the heavily lactating animal, even when a high-concentrate diet is provided, physical limitations probably prevent energy intake reaching the same high level as energy output in milk, resulting in the frequently encountered loss of body-weight at peak of lactation.

Although it is clear that these forms of production stimulate appetite, it is often difficult to vary one of them independently in order to assess its quantitative importance and mode of action. By using fully grown, non-pregnant, non-lactating cows, varying only in their degree of fatness, it should be possible, however, to relate a synthetic process to appetite both qualitatively and quantitatively. It has been shown (Bines et al. 1969 ) that thin cows will consume about $20 \%$ more of a high-concentrate dict during $5 \mathrm{~h}$ access to food than the same cows when fat. Rumen fill did not appear to limit intake in either fat or thin animals; it was concluded that intake regulation was mainly metabolic in nature and flexible in its operation, 
permitting the thin cows to eat more of the diet than the fat cows. Metabolic studies, still in progress, suggest that there is a more rapid utilization of lipogenic substrates by thin cows than by fat cows, resulting in a lower concentration of these substrates in the blood of the thin cows (Bines, unpublished). Concentration gradient is the most important factor determining the rate of absorption of volatile fatty acids (VFA) from the rumen (Annison, 1965) and rumen levels of VFA are proving to be approximately similar in the fat and the thin cows; this suggests that there is a faster absorption rate in the thin cows than in fat cows. This, in turn, may permit a higher rate of fermentation in the rumen, without a corresponding increase in rumen VFA which, in turn again, may permit a greater intake.

Signal substances and receptor sites. When animals are given a diet of concentrates ad lib., the rumen is not filled to capacity, but subsequent variation in the levels of many rumen and blood metabolites is much greater than when a roughage diet is given (Bines, 1968; Bines and Davey, unpublished). Thus, a situation exists where a chemostatic mechanism, broadly similar in its operation to that postulated for monogastric animals, may be functioning to control food intake. The problems arise in determining which metabolite, or group of metabolites, provides the signal to stop eating, and the location and nature of receptor sites.

Glucose utilization rate is thought to be an important factor in the regulation of food intake by monogastric species (see review by Kennedy, r966). In ruminants, however, glucose is not likely to be an important signal substance since no decrease in food intake has been observed following the injection of glucose into the rumen, peritoneum, jugular vein, ruminal vein or carotid artery (see Baile \& Mayer, 1970). Because VFA rather than glucose are the main products of energy digestion in ruminants, these compounds have received considerable attention as possible components of a food intake regulation system. Food intake decreases as the result of injection of VFA into the rumen of cattle (Dowden \& Jacobson, 1960; Montgomery, Schultz \& Baumgardt, 1963 ; Simkins, Suttie \& Baumgardt, 1965 ; Warner $\&$ Bhattacharya, 1968), sheep (Baile \& Pfander, r966; Ulyatt, I965; Weston, 1966) and goats (Baile \& Mayer, I967, I968a, I969; Baile, Mayer \& McLaughlin, 1969). Intraruminal infusions of acetate, propionate or VFA mixture in goats during spontaneous meals had approximately similar effects (Baile \& Mayer, 1969) whereas butyrate was considerably less effective. Increasing the acetate concentration was more effective than increasing the total acetate content without an increase in concentration (Baile, Mayer \& McLaughlin, 1969) so that the decrease in intake was proportional to the number of $\mathrm{mmol}$ injected per meal if the digesta were not diluted (Baile \& Mayer, I969).

In contrast, intravenous infusion of acetate in sheep had no effect on food intake (Holder, 1963). In cows, considerably less of an all-concentrate diet was eaten in a single meal than when $20 \%$ roughage was included in the diet (Bines \& Davey, 1970). At the end of a meal, the maximum level of acetate was appreciably higher $\left(\mathrm{r} 7^{\circ} \mathrm{O}\right.$ $\mathrm{mg} / \mathrm{r} 00 \mathrm{ml}$ ) in the plasma of the cows receiving the diet containing roughage than in those receiving the all-concentrate $\operatorname{diet}(8 \cdot 2 \mathrm{mg} / 100 \mathrm{ml})$. In the rumen, however, the highest acetate concentrations were $20 \%$ greater in the cows receiving the all- 
concentrate diet than in those receiving the diet containing roughage (Bines and Davey, unpublished). This suggests that a high ruminal concentration, rather than a high blood concentration, of acetate is likely to have caused the low intake of the concentrate diet. Baile \& Mayer (Ig68b) have shown that intraruminal addition of acetate was more effective than the same amount of acetate administered intravenously, indicating that acetate receptors are probably on the lumen side of the rumen wall. However, propionate receptors may also be present in veins draining the rumen (Baile, 1969). Within the rumen, acetate was more effective in depressing intake when injected into the dorsal sac than when injected into the ventral sac or the reticulum (Baile \& McLaughlin, 1970). The mechanism of the response to acetate and propionate is not clear; it is not a compensation for the added energy (Baile \& Mayer, 1968b, 1969) nor is it due to the increase in osmolatity or acid moiety (Baile \& Pfander, 1966; Baile \& Mayer, 1969). The neural signals arising from the rumen wall due to changes in acetate concentration in the rumen can be blocked by local anaesthetics (Martin \& Baile, I970).

\section{Conclusions}

In this paper, no mention has been made of the role of the hypothalamus in controlling feeding in ruminants, although it apparently has many of the same functions as in monogastric animals. Activation of the lateral area elicits a feeding response which is probably balanced, at least in part, against body energy depletion by the activity of the ventromedial area of the hypothalamus. This is discussed more fully in the reviews of Baile \& Mayer (1970) and Kennedy (1966). The concept of the palatability of a food has also been omitted although it may be of considerable importance in the determination of intake especially where a choice of foods is offered (Greenhalgh \& Reid, I967).

It is possible that there exists a positive control of the initiation, as well as of the termination, of eating. In the ruminant, research has been concentrated almost entirely on the search for the identity of the latter, although the work of Thye, Warner \& Miller (1970) has indicated that plasma levels of free fatty acids may act in the former role. Control of the cessation of eating appears to depend on the nature of the food given. If this contains a low level of digestible energy such that the rumen is filled before the energy requirement of the animal is met, the amount eaten at a meal will depend on the capacity of the rumen, which is closely related to the capacity of the abdominal cavity. The daily intake of such a food will depend on the rate at which it is subsequently removed from the rumen and hence on the frequency of meals. Where the digestible energy concentration of the food is sufficiently high, eating will continue until the animal has consumed enough to meet the requirements of all its productive processes. The latter will determine the rate of utilization of metabolites and hence the rate at which they accumulate, assuming that the level to which they accumulate is fixed. Evidence at present available suggests that acetate and propionate are the most important signal substances under these conditions and that sensors for these are located in or near the rumen. 


\section{REFERENCES}

Annison, E. F. (1965). In Physiology of Digestion in the Ruminant p. I85 [R. W. Dougherty, editor]. Washington, D.C. : Butterworths.

Arnold, G. W. (1966). Proc. Aust. Soc. Anim. Prod. 6, 213.

Annold, G. W. (1970). In Physiology of Digestion and Metabolism in the Ruminant p. 264 [A. T. Phillipson, editor]. Newcastle upon Tyne: Oriel Press.

Baile, C. A. (1969). Fedn Proc. Fedn Am. Socs exp. Biol. 28, 1306.

Baile, C. A. \& McLaughlin, C. L. ( 1970). F. Dairy Sci. 53, 1058.

Baile, C. A. \& Mayer, J. (1967). Am. f. Physiol. 2r3, 387.

Baile, C. A. \& Mayer, J. (r968a). Am. F. Physiol. 214, 677.

Baile, C. A. \& Mayer, J. (1968b). Y. Dairy Sci. 51, 1490.

Baile, C. A. \& Mayer, J. (1969). Am. F. Physiol. 217, 1830.

Baile, C. A. \& Mayer, J. (1970). In Physiology of Digestion and Metabolism in the Ruminant p. 254 [A. T. Phillipson, editor]. Newcastle upon Tyne: Oriel Press.

Baile, C. A. \& Pfander, W. H. (1966). Am. F. Physiol. 210, 1243.

Baile, C. A., Mayer, J. \& McLaughlin, C. (1969). Am. F. Physiol. 217, 397.

Baumgardt, B. R. (1970). In Physiology of Digestion and Metabolism in the Ruminant p. 235 [A. T. Phillipson, editor]. Newcastle upon Tyne: Oriel Press.

Bines, J. A. (1968). Proc. Nutr. Soc. 27, I5A.

Bines, J. A. \& Davey, A. W. F. (1970). Br. F. Nutr. 24, 1013.

Bines, J. A., Suzuki, S. \& Balch, C. C. $(1969)$. Br. F. Nutr. 23, 695.

Blaxter, K. L. \& Wilson, R, S. (1962). Anim. Prod. 4, 35 I.

Campling, R. C. (1966). F. Dairy Res. 33, 13.

Campling, R. C. (1970). In Physiology of Digestion and Metabolism in the Ruminant p. 226 [A. T. Phillipson, editor]. Newcastle upon Tyne: Oriel Press.

Campling, R. C. \& Freer, M. (1 g66). Br. F. Nutr. 20, 229.

Campling, R. C., Freer, M. \& Balch, C. C. (1962). Br. F. Nutr. 16, 115.

Campling, R. C., Freer, M. \& Balch, C. C. (1963). Br. F. Nutr. 17, 263.

Comline, R. S., Silver, I. A. \& Steven, D. G. (1969). In Handbook of Physiology. Alimentary Canal. Sect. 6, Vol. 5, p. 2647 [C. F. Code, editor]. Washington, D.C.: American Physiological Society.

Conrad, H. R., Pratt, A. D. \& Hibbs, J. W. (I 964). Y. Dairy Sci. 47, 54.

Dinius, D. A. \& Baumgardt, B. R. (1970). F. Dairy Sci. 53, 3 I I.

Dowden, D. R. \& Jacobson, D. R. (1960). Nature, Lond. 188, 48.

Forbes, J. M. (1969). F. agric. Sci., Camb. 72, 119.

Forbes, J. M. (I970). Br. vet. 7. 126, 1.

Freer, M. \& Campling, R. C. (1963). Br. F. Nutr, 17, 79.

Graham, N. McC. \& Williams, A. J. (1962). Aust. F. agric. Res. 13, 894.

Greenhalgh, J. F. D. \& Reid, G. W. (1967). Nature, Lond. 214, 744.

Holder, J. M. (1963). Nature, Lond. 200, ro74.

Kennedy, G. C. (1966). Br. med. Bull. 22, 2 I6.

Lamberth, J. L. (1969). Aust. F. exp. Agric. Anim. Husb. 9, 493.

Leaver, J. D., Campling, R. C. \& Holmes, W. (r969). Anim. Prod. r1, г r.

Martin, F. H. \& Baile, C. A. (1970). F. Anim. Sci. 31, 248.

Minson, D. J. (1963). F. Br. Grassld Soc. 18, 39.

Montgomery, M. J., Schultz, L. H. \& Baumgardt, B. R. (1963). f. Dairy Sci. 46, 1380.

Pearce, G. R. (1967). Aust. F. agric. Res. 18, x 19.

Simkins, K. L., Suttie, J. W. \& Baumgardt, B. R. (1965). F. Dairy Sci. 48, 1635.

Tayler, J. C. (1959). Nature, Lond. 184, 2021.

Thye, F. W., Warner, R. G. \& Miller, P. D. (1970). J. Nutr. 100, 565.

Ulyatt, M. J. (1965). N.Z. 7 l agric. Res. 8, 397.

Warner, R. G. \& Bhattacharya, A. N. (1968). F. Dairy Sci. 5r, rogr.

Weston, R. H. (1966). Aust. F. agric. Res. r7, 939.

\section{The regulation of body-weight in man}

\section{By R. PAssmore, Department of Physiology, University of Edinburgh}

The words 'regulate' and 'control' would appear to be used on our programme, as if they were synonymous. I think it helps if they are distinguished and each is 